\title{
RANCANG BANGUN APLIKASI MOBILE UNTUK MENENTUKAN SOLUSI OPTIMAL PENCARIAN RUTE TERBAIK MENGGUNAKAN ALGORITMA ANT COLONY OPTIMIZATION
}

\author{
Budhi Irawan ${ }^{1}$, Casi Setianingsih ${ }^{2}$, Izzat Arramsyah ${ }^{3}$ \\ 1'budhiirawan@telkomuniversity.ac.id, ${ }^{2}$ setiacasie@telkomuniversity.ac.id, ${ }^{3}$ arramsyah@gmail.com \\ 1,2,3 Prodi Sistem Komputer, Fakultas Teknik Elektro, Universitas Telkom
}

\begin{abstract}
Abstrak
Dampak dari musibah kebakaran bisa ditekan jika petugas dan kendaraan Damkar (pemadam kebakaran) bisa bekerja cepat. Selain faktor keterlambatan laporan kepada Damkar dan kondisi jalan Kota Bandung yang macet ikut memperlambat laju petugas. Proses pengisian tangki air menjadi masalah utama, selain terbatas keberadaannya juga kualitas semburannya rendah sehingga petugas harus mencari sumber air selain hydrant. Dari permasalahan tersebut maka dibutuhkan suatu alat bantu yang praktis berupa aplikasi dengan memanfaatkan perangkat smartphone yang dapat membantu mencarikan solusi optimal guna mendapatkan rute perjalanan petugas Damkar dalam upaya menjangkau lokasi kebakaran dan mendapat sumber air didalam mendukung tugasnya memadamkan api di lokasi kebakaran. Adapun guna menentukan rute optimal sesuai kebutuhan diatas maka dipilih algoritma ACO (Ant Colony Optimization) dan Metode SAW (Simple Additive Weighting) yang diimplementasikan pada aplikasi mobile yang dibangun. Sehingga dengan aplikasi ini dapat membantu para petugas Damkar didalam menjalankan tugasnya terutama mendapatkan rute jalan yang optimal beserta sumber air yang diperlukan.
\end{abstract}

Kata kunci : Simple Additive Weighting, Ant Colony Optimization, Aplikasi Mobile

\section{Pendahuluan}

Jumlah peredaran kendaraan di Kota Bandung setiap hari kini semakin padat. Simpul kemacetan terus bertambah di sejumlah ruas jalan. Kondisi seperti itu salah satunya menghambat laju kendaraan Damkar di kota berpenduduk cukup padat ini. Kasus kebakaran yang paling banyak biasanya api membakar kawasan permukiman padat dan separuh total kasus kebakaran lainnya menimpa pabrik, bangunan umum, dan juga gardu listrik. Umumnya penyebab kebakaran diduga karena arus pendek listrik. Besarnya dampak musibah kebakaran bisa ditekan jika petugas dan kendaraan Damkar bisa bekerja dengan relatif cepat. Selain faktor keterlambatan laporan warga ke pihak Damkar dan kondisi jalan didalam kota yang kian macet maka ikut memperlambat laju petugas dari markas ke lokasi kejadian.. Pada jam lalu lintas sibuk dari pagi hingga petang, pengemudi harus menemukan jalan alternatif hingga terpaksa melawan arus. Selain itu yang menjadi masalah juga adalah proses pengisian tangki air yang mana, dari beberapa hydrant yang ada, hanya ada sedikit yang dapat berfungsi dan menyembur kuat untuk mengisi tangki dengan cepat. Apabila semburannya kecil maka petugas harus mencari sungai atau hydrant milik instansi atau pabrik terdekat.

Algoritma ACO diadopsi dari perilaku koloni semut yang dikenal sebagai sistem semut. Secara alamiah koloni semut mampu menemukan rute terpendek dalam perjalanan dari sarang menuju ke sumber makanan dan kembali lagi. Pada saat semut berjalan, semut meninggalkan sebuah informasi yang disebut pheromone di tempat yang dilaluinya dan menandai rute tersebut. Pheromone digunakan sebagai komunikasi antar semut pada saat membangun rute[1, 2, 3, 4]. Sedangkan metode SAW adalah salah satu metode yang dapat digunakan untuk menyelesaikan masalah MADM (Multi-Attribute Decision Making). Metode ini mencari alternatif terbaik, dengan mengevaluasi alternatif terhadap sekumpulan atribut atau kriteria[1, 4, 5, 6].

Dari permasalahan diatas maka dibutuhkan suatu alat bantu yang dapat membantu mencarikan solusi optimal guna mendapatkan rute terbaik perjalanan petugas Damkar dalam upaya menjangkau lokasi kebakaran dan mendapat sumber air didalam mendukung tugasnya memadamkan api, dalam hal ini diimplementasikan berupa aplikasi dengan memanfaatkan perangkat smartphone. Adapun guna menentukan rute optimal sesuai kebutuhan diatas maka dipilih algoritma ACO dan metoda SAW yang diimplementasikan pada aplikasi mobile yang dibangun.

\section{Metode}

\subsection{Metode SAW}


Metode SAW sering dikenal dengan istilah metode penjumlahan terbobot. Konsep dasar dari medote SAW ini adalah mencari penjumlahan terbobot dari rating kinerja pada setiap alternatif pada semua atribut. Metode ini membutuhkan proses normalisasi matriks keputusan ke suatu skala yang dapat diperbandingkan dengan semua rating alternatif yang ada [8].

$r_{i j}= \begin{cases}\frac{x_{i j}}{\operatorname{Max} x_{i j}} & \text { Jika j adalah atribut keberuntungan (benefit) } \\ \frac{\operatorname{Min} x_{i j}}{x_{i j}} & \text { Jika j adalah atribut biaya (cost) }\end{cases}$

dimana :

$\mathrm{r}_{\mathrm{ij}}=$ rating kinerja ternormalisasi dari alternatif $\mathrm{A}_{\mathrm{i}}$ pada atribut $\mathrm{Cj}$

di mana $\mathrm{i}=1,2, \ldots, \mathrm{m}$ dan $\mathrm{j}=1,2, \ldots, \mathrm{n}$.

Nilai preferensi untuk setiap alternatif diberikan sebagai :

$V_{i}=\sum_{j=1}^{n} w_{j} r_{i j}$

Nilai Vi yang lebih besar mengindikasikan bahwa alternatif $\mathrm{Ai}$ lebih terpilih. Langkah-langkah dari metode SAW adalah :

1. Menentukan kriteria-kriteria yang akan dijadikan acuan dalam pengambilan keputusan,

2. Menentukan rating kecocokan setiap alternatif pada setiap kriteria,

3. Membuat matriks keputusan berdasarkan kriteria (C), kemudian melakukan normalisasi matriks berdasarkan persamaan yang disesuaikan dengan jenis atribut (atribut keuntungan ataupun atribut biaya) sehingga diperoleh matriks ternormalisasi $R$,

4. Hasil akhir diperoleh dari proses perankingan yaitu penjumlahan dari perkalian matriks ternormalisasi $R$ dengan vektor bobot sehingga diperoleh nilai terbesar yang dipilih sebagai alternatif terbaik $(A)$ sebagai solusi [8].

\subsection{Algoritma ACO}

Algoritma ACO terinspirasi dari perilaku sosial koloni semut dimana seekor semut dapat menjangkau sumber makanan dengan rute terdekat dari sarangnya dengan memanfaatkan material kimia yang disebut pheromone yang dilepaskannya pada saat berjalan. Pheromone tersebut akan menarik perhatian semut lain untuk mengikuti suatu rute [9].

Pada algoritma ACO digunakan istilah pheromone yang menunjukan intenstias jejak pada suatu edge. Setiap semut akan meninggalkan jejak setiap mereka melewati jalur. Semakin banyak jumlah pheromone yang ada pada suatu rute, semakin potensial rute tersebut untuk diikuti oleh semut-semut lainnya [10].

\subsection{Algoritma ACS (Ant Colony System)}

Algoritma ACS adalah bagian dari pengembangan Algoritma Ant System. Algoritma tersebut disusun dengan sekumpulan $m$ semut yang bekerjasama dan melakukan komunikasi secara tidak langsung melalui komunikasi pheromone. Adapun algoritma ACS berjalan sebagai berikut yaitu pertama-tama sejumlah $\mathrm{m}$ semut ditempatkan pada sejumlah $\mathrm{n}$ titik berdasar kepada beberapa aturan inisialisasi. Setiap semut akan membuat sebuah solusi (tour) dengan cara menerapkan sebuah aturan transisi status secara berulang kali. Selama membangun toumya, setiap semut memodifikasi jumlah pheromone pada edge-edge yang akan dikunjunginya dengan menerapkan aturan pembaruan pheromone lokal. Setelah semua semut mengakhiri tour, jumlah pheromone yang ada pada edge-edge dimodifikasi kembali dengan cara menerapkan aturan pembaruan pheromone global. Seperti yang terjadi pada AS, dalam membuat tour, semut dipandu oleh adanya informasi heuristic yaitu mereka lebih memilih edge-edge yang pendek dan informasi pheromone. Sebuah edge dengan jumlah pheromone yang tinggi merupakan suatu pilihan yang sangat diinginkan. Kedua aturan pembaruan pheromone itu dirancang agar supaya semut cenderung untuk memberi lebih banyak pheromone pada edge-edge 
yang harus mereka lewati. Karakteristik utama dari ACS diantara yaitu aturan transisi status, aturan pembaharuan pheromone global, dan aturan pembaharuan pheromone lokal [11].

\subsubsection{Aturan Transisi Status}

Aturan dari transisi status yang berlaku pada ACS yang ditunjukkan pada persamaan (3) yang mana semut $k$ yang berada di titik $r$, akan pemilihan titik berikutnya $s$, menurut persamaan sebagai berikut :

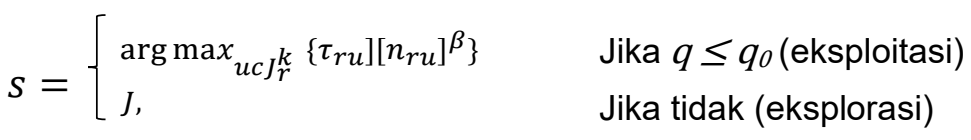

Dimana $\mathrm{q}$ adalah bilangan random dalam $[0,1], \mathrm{q}_{0}\left(\begin{array}{ll}0 & 1\end{array}\right) \leq \mathrm{q}_{0} \leq$ adalah sebuah parameter pembanding bilangan random, dan J adalah probabilitas dari semut k pada titik $r$ yang akan melakukan pemilihan untuk menuju kepada titik $S$ yang ditunjukan pada persamaan (4) berikut ini.

$P_{r s}^{k}= \begin{cases}\frac{\left[\tau_{r s}\right]^{\alpha}\left[n_{r s}\right]^{\beta}}{\left.\sum_{u c J_{r}^{k}} \tau_{r u}\right]\left[n_{r u}\right]^{\beta}} & \text { Untuk s } \in \mathrm{j}_{\mathrm{r}}{ }^{k} \\ 0 & \text { Untuk s lainnya }\end{cases}$

Dimana $\tau_{\mathrm{rs}}$ adalah jumlah pheromone yang terdapat pada edge antara titik $\mathrm{r}$ dan titik $\mathrm{s}$ dan $\eta_{\mathrm{rs}}$ adalah visiblitty. a merupakan suatu parameter yang melakukan pengontrolan terhadap bobot (weight) relatif dari pheromone dan $\beta$ merupakan suatu parameter pengendali dari jarak ( $\alpha>0$ dan $\beta>0$ ). Pada persamaan (3), pheromone pada edge $(\mathrm{r}, \mathrm{s})$ dikalikan dengan suatu nilai visibility yang sesuai $\left(\eta_{\mathrm{rs}}\right)$. Dengan menggunakan cara ini maka akan dilakukan proses pemilihan edge yang lebih pendek dan memiliki jumlah pheromone yang lebih besar. Dengan istilah lain, Jika $q \leq q o$ maka semut tersebut akan dapat memanfaatkan pengetahuan heuristik mengeai jarak antara titik itu dengan titik-titik lainnya dan juga pengetahuan yang telah diperoleh akan disimpan dalam bentuk pheromone. Hal ini mengakibatkan edge yang paling baik berdasarkan kepada persamaan (3) akan dipilih. Jika sebaliknya maka sebuah edge dan dilakukan pemilihan berdasarkan persamaan (4) [11].

\subsubsection{Aturan Pembaharuan Pheromone Lokal}

Pada saat akan membangun tour, semut mengimplementasikan local updating rule berdasarkan persamaan berikut :

$\tau_{r s} \leftarrow(1-\xi) \tau_{r s}+\xi \tau_{o}$

$\xi$ merupakan sebuah parameter evaporasi lokal $0<\xi<1.0 \tau$ merupakan sebuah nilai awal jejak pheromone, $\tau_{0}=1 / \mathrm{n} \mathrm{C}_{\mathrm{nn}}$ dimana $\mathrm{n}$ adalah jumlah dari titik dan $\mathrm{C}_{\mathrm{nn}}$ merupakan panjang sebuah tour yang paling baik yang diperoleh dari metode nearest neighbourhood heuristic. Persamaan update pheromone online ini diimplementasikan pada saat semut membangun tour, yaitu ketika akan melewati edge dan melakukan pengubahan tingkat pheromone pada edge $(\mathrm{r}, \mathrm{s})$. Tujuan dari kegiatan tersebut adalah guna membantu melewati sebuah edge, yang mana edge ini akan menjadi kurang diinginkan karena berkurangnya jejak pheromone pada edge yang bersesuaian tersebut.[11].

\subsubsection{Aturan Pembaharuan Pheromone Global}

Apabila semua semut sudah menyelesaikan sebuah tour, tingkat pheromone akan di-update dengan mengimplementasikan global updating rule berdasar kepada persamaan (6) berikut :

$\tau_{r s} \leftarrow(1-\rho) \tau_{r s}+\rho \Delta \tau_{o}$ 
Dimana :

$\Delta \tau(r, s)=\left(L_{g b}\right)^{-1} \quad, j i k a(r, s) \in$ rute terbaik keseluruhan

Dimana $\rho$ merupakan sebuah parameter evaporasi global, yang mempunyai nilai $0<\rho<1$. $\rho \tau$ merupakan skala 1 / panjangdari lintasan yang paling baik secara keseluruhan, jika (i,j) merupakan bagian dari panjang lintasan yang paling baik secara keseluruhan.

Pada persamaan dari update jejak pheromone secara offline ini, dilakukan pada bagian akhir dari proses iterasi algoritma, saat dari semua semut sudah menyelesaikan sebuah tour. Persamaan diimplementasikan ke edge yang akan digunakan semut guna menemukan lintasan keseluruhan yang paling baik sejak awal penelusuran. Tujuan dari proses pemberian nilai ini adalah guna memberikan sejumlah jejak pheromone pada lintasan yang paling pendek, dimana tour terbaik akan mendapat penguatan. Bersama dengan pseudo-random proportional rule dimaksudkan untuk dapat membuat proses pencarian menjadi lebih terarah [11].

\section{Hasil dan Pembahasan}

\subsection{Rancanngan SAW}

Metode SAW merupakan metode pengambilan keputusan dengan banyak kriteria. Pada aplikasi ini, metode SAW digunakan untuk melakukan pengolahan data kriteria Jarak, Posisi Hydrant dan Kemacetan. Masing-masing kriteria terdiri matriks yang menggambarkan hubungan antar node. B

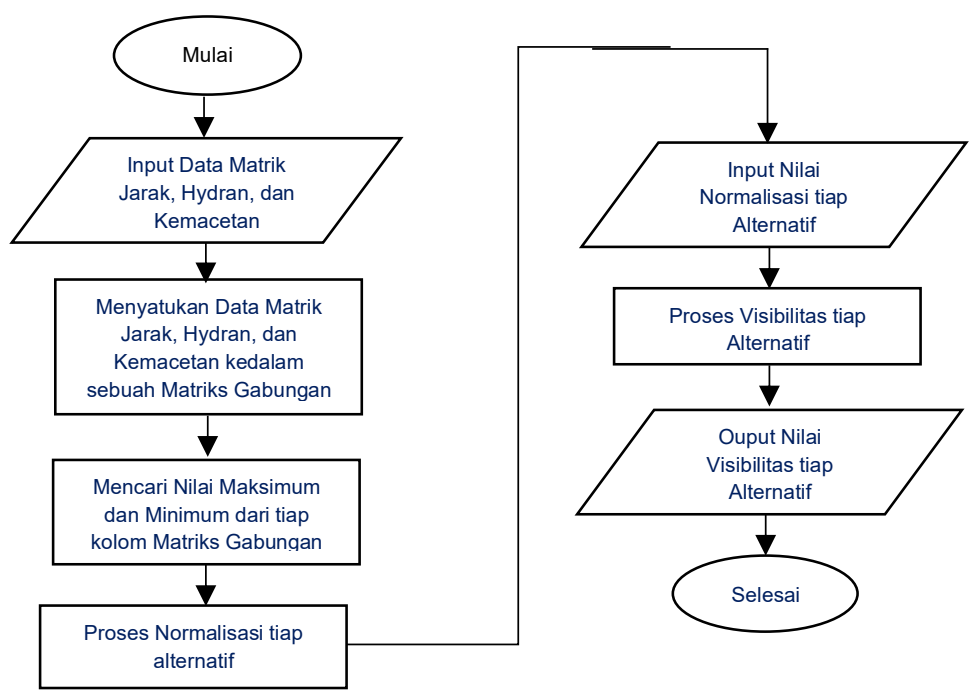

Gambar 1. Diagram Alur SAW

Pada gambar 1 ditunjukan cara kerja metode SAW pada aplikasi yang dibuat. Matriks jarak, posisi hydrant dan kemacetan didapatkan dari basisdata aplikasi. Matriks jarak, posisi hydrant dan kemacetan yang terbentuk selanjutnya dilakukan normalisasi dan untuk melakukan proses normalisasi diperlukan penentuan kriteria benefit (Keuntungan) atau kriteria cost (Kerugian) pada masing-masing kriteria. Matriks normalisasi yang terbentuk selanjtunya akan akan dijadikan satu matriks yaitu matriks akhir preferensi. Matriks inilah yang digunakan untuk pengambilan keputusan. Nilai akhir preferensi terbaik merupakan pilihan alternatif yang terbaik pula.

\subsection{Rancangan ACS}

Pada aplikasi ini, algoritma ACS digunakan sebagai penentuan rute optimal. Matriks akhir preferensi yang didapat setelah melalui proses oleh metode SAW selanjtunya digunakan pada algorimta sebagai nilai Visibilitas. Nilai Visibilitas ini merupakan nilai yang menggambarkan kualitas suatu edge. 


\section{ILKOM Jurnal Ilmiah Volume 10 Nomor 1 April 2018}

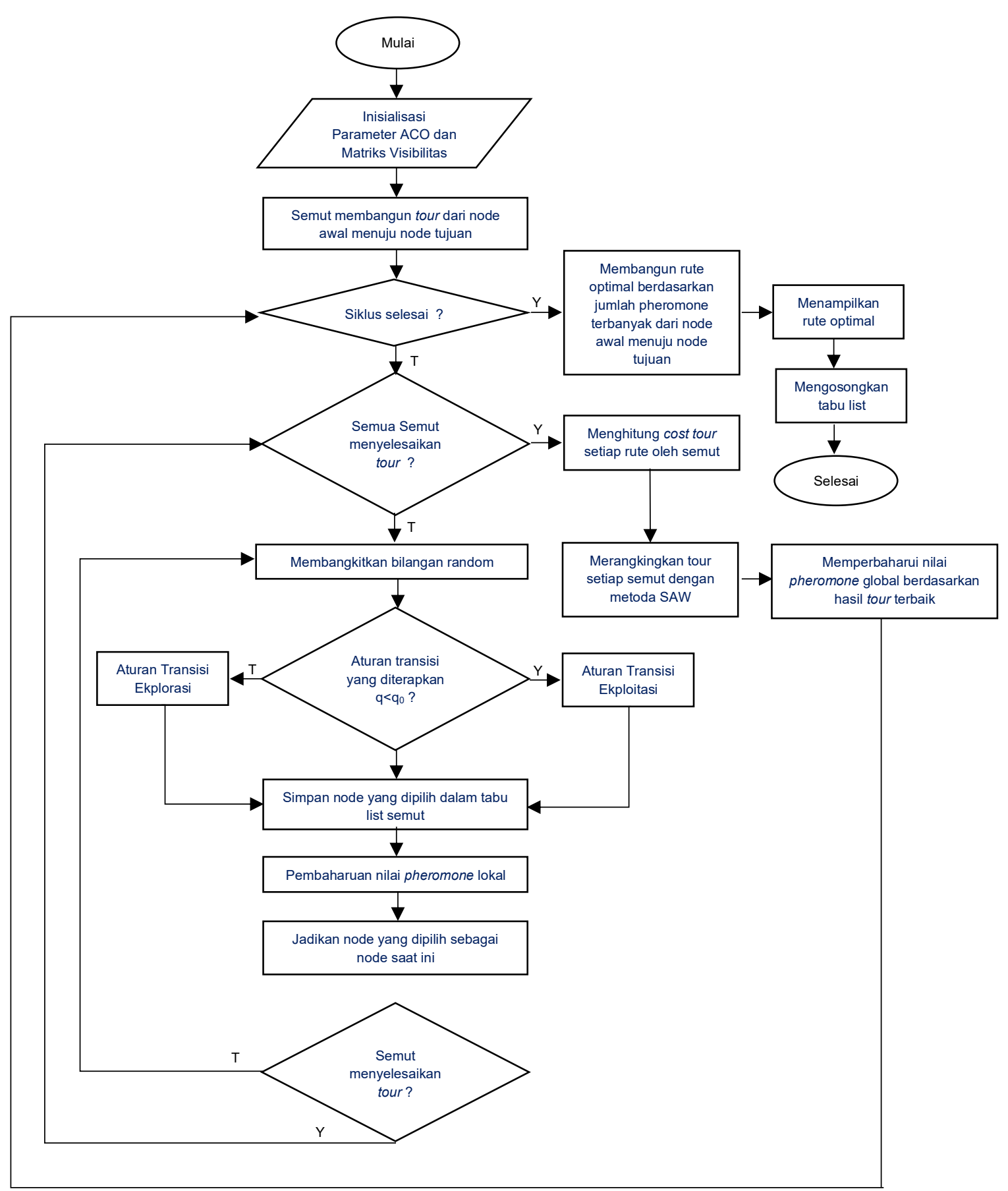

Gambar 2 Diagram Alur Algoritma ACS

Pada gambar 2 merupakan alur kerja dari algoritma ACS digunakan pada sistem. Berikut adalah penjelasan dari masing-masing tahap :

1. Menginisialisasi Parameter Algoritma ACS yang meliputi : Intensitas pheromone $\left(\tau_{\mathrm{ij}}\right)$, $\mathrm{q}_{0}$ ( Paramter pembanding bilangan random ), Parameter pengendali intensitas pheromone $(\alpha)$, Parameter pengendali Visibilitas $(\beta)$, Jumlah Semut $(m)$, Paramter penguapan pheromone $(\rho)$, Jumlah Siklus Maksimum (NCmax)

2. Semut akan ditempatkan di titik awalnya yang kemudian semut akan melakukan toumya dengan memilih node selanjutnya. Dalam memilih node selanjutnya, semut menggunakan aturan transisi status. Untuk menentukan aturan transisi yang digunakan, oleh karena itu perlu dibangkitkan suatu bilangan secara random (q) antara 0 sampai 1 sebagai acuan untuk memilih aturan transisi yang akan digunakan. Berikutnya bilangan random telah dibangkitkan ini kemudian dibandingkan dengan 
nilai parameter q0 yang telah ditetapkan. Penetapan parameter qo ini berpengaruh kepada pemilihan aturan transisi yang digunakan. Misal, jika parameter q0 yang digunakan sebesar 0.9 artinya bahwa semut akan melakukan suatu proses eksploitasi dengan nilai probabilitas sekitar $90 \%$ dan eksplorasi sebesar $10 \%$. Setelah didapatkan hasil perbandingan antara nilai q dengan nilai qo maka selanjutnya akan di tentukan aturan transisi yang digunakan. Aturan transisi ini berdasarkan persamaan (3) atau persamaan (4) dengan ketentuan :

a) Jika $q \leq q$ o maka digunakan aturan transisi eksploitasi persamaan (3)

b) Jika $q>q o$ maka digunakan aturan trasisi eksplorasi dengan perasmaan (4)

3. Setelah didapatkan node yang dituju maka selanjutnya dilakukan proses penyimpanan node tersebut ke dalam tabu list. Tabu List ini digunakan sebagai memori bagi semut untuk menyimpan hasil pencarian rutenya. Selain itu juga mencegah semut untuk mengujungi node yang telah dilewati.

4. Pada Algoritma ACS, pembaharuan nilai pheromone dilakukan pada sisi yang dilewati semut (Pembaharuan Pheromone Lokal). Pembaharuan ini dilakukan setiap semut melewati node. Pembaharuan pheromone ini menggunakan persamaan (5) dan pembaharuan pheromone ini dimaksudkan agar daya tarik pada sisi tersebut menjadi berikurang (evaporasi atau penguapan). Sehingga semut lainnya tidak akan melewati sisi tersebut. Sisi yang lebih pendek atau sisi dengan kadar pheromone yang banyak akan lebih dipilih untuk dikunjungi semut.

5. Kemudian, setelah didapatkan node beriktunya maka menjadikan node tersebut sebagai node saat ini. Kemudian dilakukan proses pencarian rute dengan mengulangi langkah 2 hingga 4 sampai seluruh semut menyelesaikan toumya atau menemukan node tujuan.

6. Setelah seluruh semut $m$ enyelesaikan toumya, setiap tour yang dihasilkan kemudian akan dipilih tour terbaik dan pemilihan tour terbaik ini menggunakan metode perangkingan antar tour yang dihasilkan menggunakan metode SAW.

7. Setelah didapatkan tour terbaik, kemudian dilakukan pembaharuan pheromone global pada isi tabu list semut dengan tour terbaik tersebut. Pembaharuan pheromone global ini menggunakan persamaan (6) dan pembaharuan pheromone global ini dimaksudkan agar kadar pheromone pada sisi tour terbaik semut tersebut mengalami penguatan dan sisi yang tidak menjadi bagian tour terbaik mengalami penguapan. Sehingga, pada siklus berikutnya pencarian lebih terarah. Isi tabu list tour terbaik tersebut di simpan kedalam tabu list rute terbaik yang kemudian dilakukan kembali proses pencarian pada siklus selanjutnya dengan nilai pheromone yang telah di perbaharui pada prsoes pembaharuan pheromone global.

8. Selanjutnya, isi tabu list di kosongkan untuk di isi kembali oleh siklus berikutnya dan proses pencarian rute oleh semut dilakukan sampai seluruh siklus selesai. Setelah proses pencarian selesai maka akan terlihat pada sisi pheromone tour terbaik akan mengalami penguatan. Jalan atau sisi yang menjadi tour terbaik inilah yang akan ditampilkan sebagai hasil pencarian rute optimal.

\subsection{Rancangan Area Pemetaan Wilayah}

Perancangan wilayah yang diimplementasikan pada aplikasi menggunakan software JOSM (Java OpenStreetMap Editor).

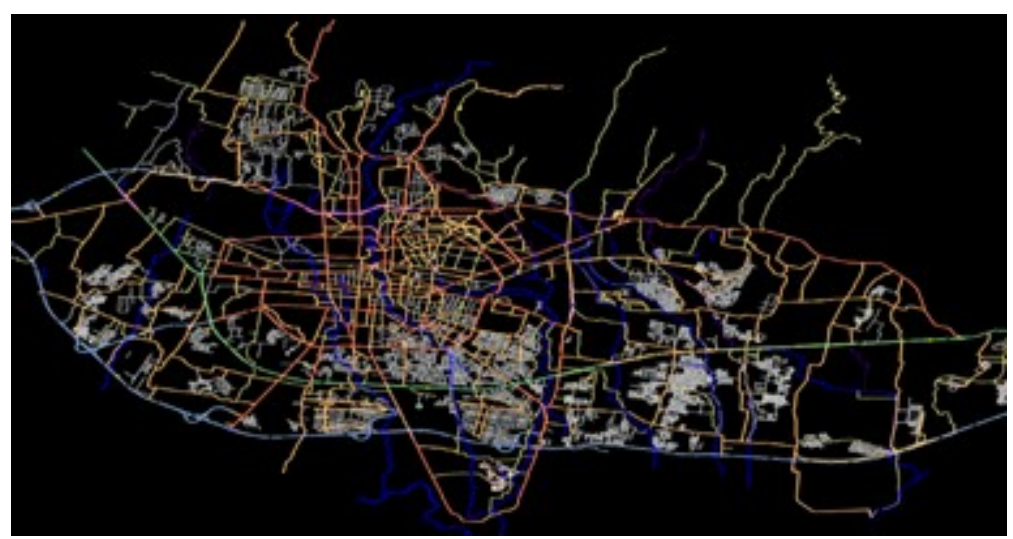

Gambar 3 Rancangan Area Pemetaan Wilayah Kota Bandung

Pada gambar 3 ditunjukan hasil rancangan jalan utama kota Bandung yang digunakan pada aplikasi ini. Dari perancangan jalan menggunakan software JOSM ini bisa didapatkan data tiap node. Dimana tiap node ini memiliki id node, latitude, longitude dan data node ini bisa berupa persimpangan 


\section{ILKOM Jurnal Ilmiah Volume 10 Nomor 1 April 2018}

jalan atau bagian dari jalan yang berbelok juga selain itu bisa didapatkan juga data jalan yang menyatakan sebuah edge atau jalan yang terdiri dari dua node atau lebih.

\subsection{Perancangan Aplikasi}

Pada perancangan aplikasi ini menggunakan pemodelan UML (Unified Model Languange) diantaranya berupa Use Case Diagram dan Sequence Diagram.

\subsubsection{Use Case Diagram}

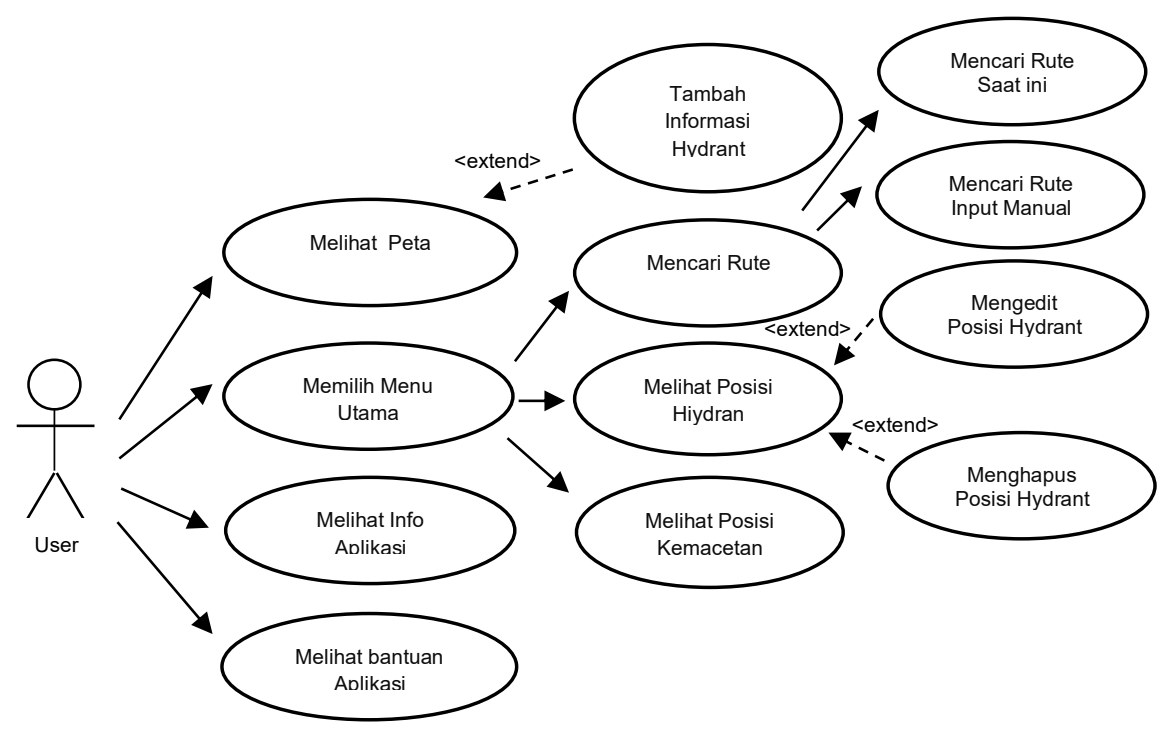

Gambar 4. Use Case Diagram

Pada gambar 4 ditunjukan interaksi antara pengguna dan aplikasi yang mana, pengguna dapat melihat peta, melihat peta, mencari rute, melihat posisi hydrant, dan melihat posisi kemacetan.

\subsubsection{Sequence Diagram}

Pada gambar 5 dibawah ini ditunjukan proses sekuensial yang terjadi pada saat membuka bagian utama aplikasi. Pada proses ini dilakukan beberapa proses navigasi, reroute, pencarian hydrant dan kalkulasi kemacetan.

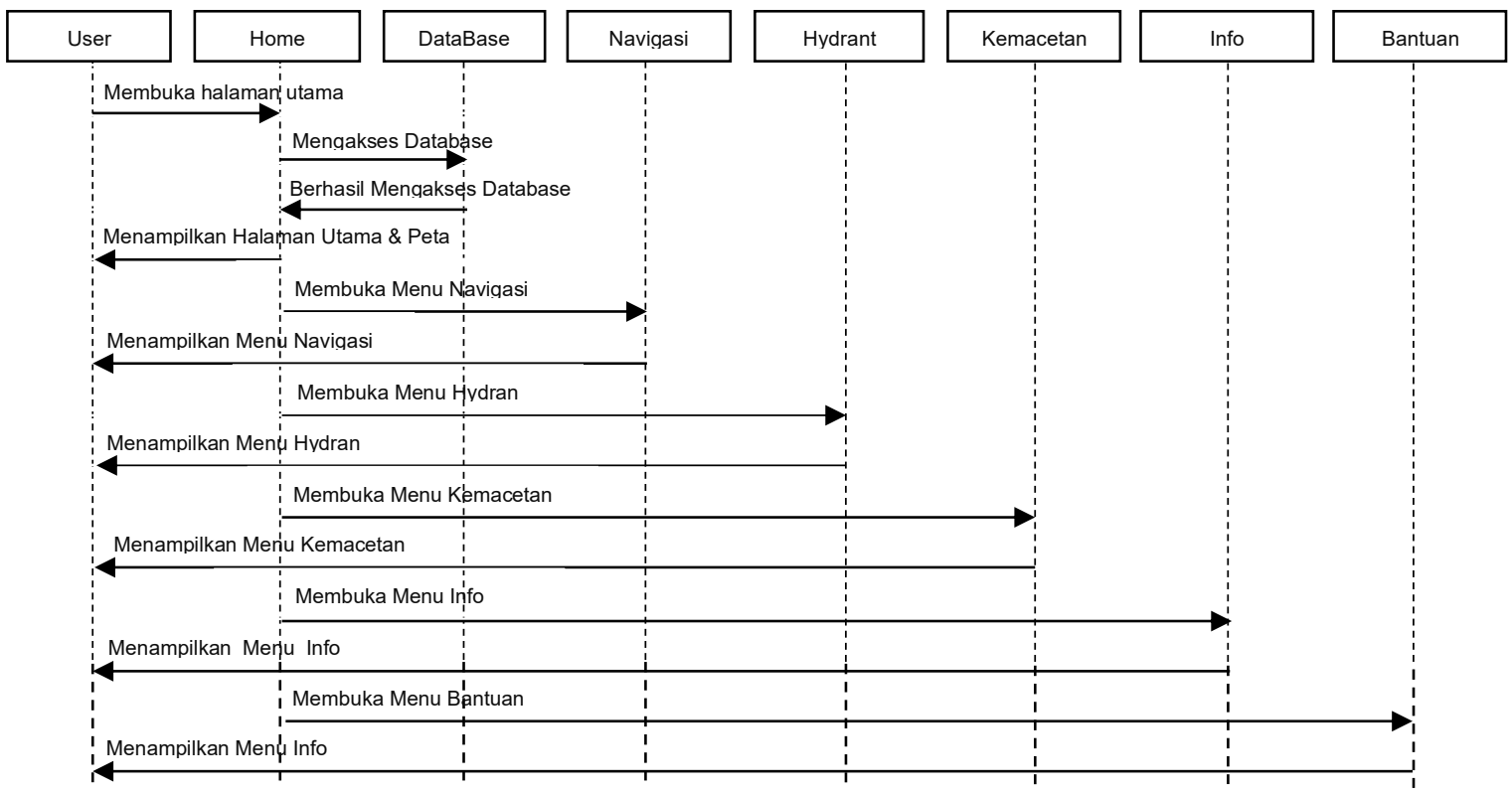

Gambar 5. Sequence Diagram Bagian Utama Aplikasi 


\subsubsection{Rancangan Antarmuka Aplikasi}

Pada gambar 6 dibawah ini ditunjukan proses rancangan antarmuka utama aplikasi. Pada antarmuka ini ditampilkan layout property aplikasi mobile yang meliputi halaman utama beserta halaman-halaman detilnya.
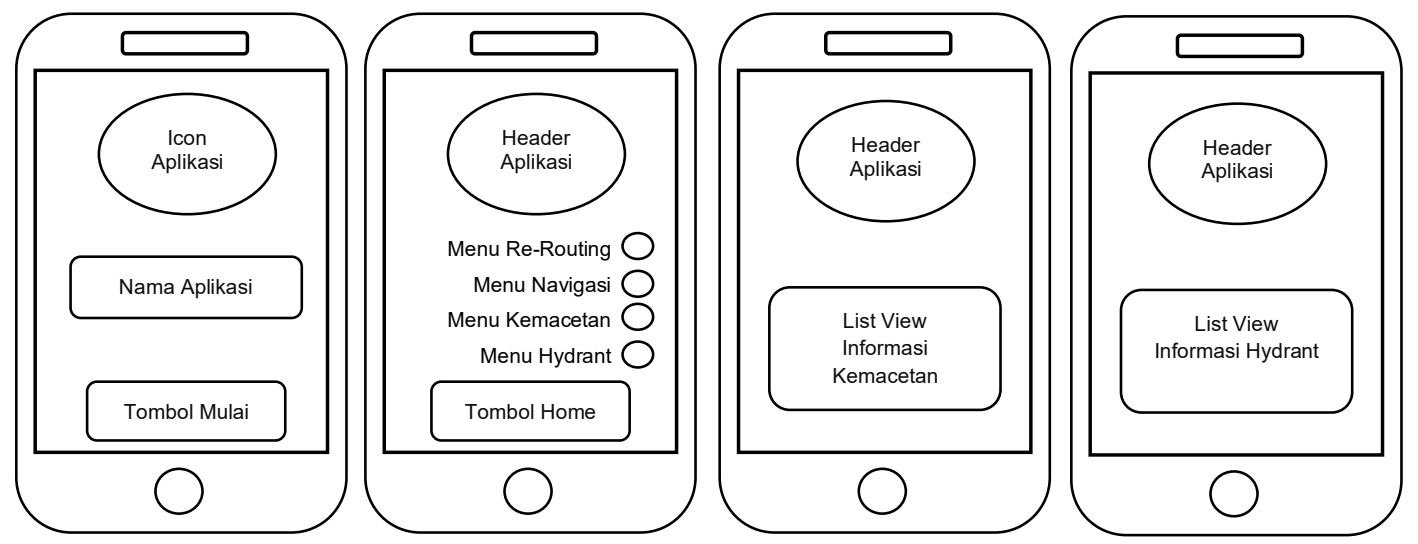

Gambar 6. Rancangan Antarmuka

\subsection{Pengujian Sistem}

\subsubsection{Pengujian Medode SAW dan ACS}

Pada pengujian metode SAW dan algortima ACS ini diperlukan sebuah skenario pemetaan jalan yang digunakan oleh metode SAW untuk melakukan bobot jalan dengan perhitungan kriteria jarak, kemacetan dan posisi. Serta algoritma ACS dalam melakukan pencarian rute.

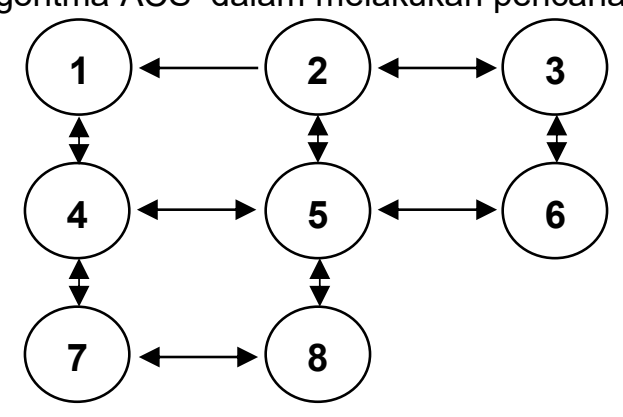

Gambar 8. Skenario Pemetaan Jalan

Keterangan :

1. $\rightarrow \quad:$ :dge (Arah Hubungan) Satu Arah Dari Node Awal Ke Node Tujuan

2. $\rightarrow$ : Edge (Arah Hubungan) Dua Arah Dari Node Awal Ke Node Tujuan

3. : Node atau Titik Persimpangan

Pada gambar 8 menggambarkan pemetaan jalan yang digunakan untuk pengujian metode SAW dan Algoritma ACS. Proses pemetaan jalan digambarkan dengan node dan edge.

Tabel 1. Keterangan Pemetaan Jalan

\begin{tabular}{|c|c|c|c|c|c|c|}
\hline No & Edge & Nama Jalan / Edge & $\begin{array}{c}\text { Jarak } \\
(\mathrm{KM})\end{array}$ & Kemacetan & Hydrant & $\begin{array}{c}\text { Satu } \\
\text { Arah }\end{array}$ \\
\hline 1 & $1 \rightarrow 2$ & Jl. Belakang Pasar & 0,1838 & 0,1 & 0 & -1 \\
\hline 2 & $1 \rightarrow 4$ & Jl. Gardujati & 0,1737 & 0,1 & 0 & 0 \\
\hline 3 & $2 \rightarrow 3$ & Jl. Belakang Pasar 1 & 0,1649 & 0,1 & 0 & 0 \\
\hline 4 & $2 \rightarrow 5$ & Jl. Durman & 0,1878 & 0,5 & 0 & -1 \\
\hline 5 & $3 \rightarrow 6$ & Jl. Babatan & 0,2237 & 0,1 & 0 & 0 \\
\hline 6 & $5 \rightarrow 4$ & Jl. Ence Ajis & 0,1538 & 0,8 & 0 & 0 \\
\hline 7 & $4 \rightarrow 7$ & Jl. Astana Anyar & 0,1532 & 0,1 & 1 & 0 \\
\hline 8 & $8 \rightarrow 5$ & Jl. Durman 1 & 0,1577 & 0,1 & 0 & 0 \\
\hline 9 & $6 \rightarrow 5$ & Jl. Ence Ajis 1 & 0,1629 & 0,1 & 1 & 0 \\
\hline 10 & $7 \rightarrow 8$ & Jl. Jendral Sudirman & 0,1566 & 0,1 & 0 & 0 \\
\hline
\end{tabular}


Keterangan :

$\rightarrow:$ Menuju Node

Pada Tabel 1 merupakan rincian keterangan pemetaan node dan edge yang digunakan pada pengujian. Berikut adalah penjelasan dari masing-masing kolom.

1. Kolom Jarak : Menyatakan jarak antar node.

2. Kolom kemacetan : Menyatakan bobot kemacetan antar node.

3. Kolom Hydrant : Menyatakan posisi hydrant. Jika pada kolom tersebut terdapat nilai 1, maka antara node tersebut terdapat hydrant. Sedangkan nilai 0 menyatakan antara node tersebut tidak memiliki hydrant.

4. Kolom satu arah : Menyatakan hubungan antar node tersebut. Nilai 0 menandakan antara node tersebut saling terhubung. Sedangkan nilai -1 menandakan arah dari hubungan satu arah antar node.

\subsubsection{Perbandingan Hasil Pengujian dengan cara Manual dan Metoda SAW}

Hasil perhitungan antara perhitungan dengan cara manual dan perhitungan oleh sistem pada aplikasi memiliki nilai yang sama. Namun pada sistem digunakan pembulatan angka. Dapat disimpulkan bahwa hasil pengujian perhitungan sistem telah berjalan dengan benar.

Tabel 2 Perbandingan Perhitungan Manual Dengan Sistem Metode SAW

\begin{tabular}{|c|c|c|c|c|}
\hline No & Alternatif & Perhitungan Manual & Keluaran Sistem & Hasil \\
\hline 1 & $1 \rightarrow 4$ & 0.7079 & 0.708 & $\sqrt{ }$ \\
\hline 2 & $2 \rightarrow 1$ & 0.7312 & 0.731 & $\sqrt{ }$ \\
\hline 3 & $3 \rightarrow 2$ & 0.7548 & 0.755 & $\sqrt{ }$ \\
\hline 4 & $3 \rightarrow 6$ & 0.6347 & 0.635 & $\sqrt{ }$ \\
\hline 5 & $4 \rightarrow 1$ & 0.7079 & 0.708 & $\sqrt{ }$ \\
\hline 6 & $4 \rightarrow 5$ & 0.5377 & 0.538 & $\sqrt{ }$ \\
\hline 7 & $4 \rightarrow 7$ & 0.9872 & 0.987 & $\sqrt{ }$ \\
\hline 8 & $5 \rightarrow 4$ & 0.5377 & 0.538 & $\sqrt{ }$ \\
\hline 9 & $5 \rightarrow 6$ & 0.9603 & 0.960 & $\sqrt{ }$ \\
\hline 10 & $5 \rightarrow 2$ & 0.4768 & 0.477 & $\sqrt{ }$ \\
\hline 11 & $5 \rightarrow 8$ & 0.7747 & 0.775 & $\sqrt{ }$ \\
\hline 12 & $6 \rightarrow 3$ & 0.6347 & 0.635 & $\sqrt{ }$ \\
\hline 13 & $6 \rightarrow 5$ & 0.9603 & 0.960 & $\sqrt{ }$ \\
\hline 14 & $7 \rightarrow 4$ & 0.9872 & 0.987 & $\sqrt{ }$ \\
\hline 15 & $7 \rightarrow 8$ & 0.7779 & 0.778 & $\sqrt{ }$ \\
\hline 16 & $8 \rightarrow 5$ & 0.7747 & 0.775 & $\sqrt{ }$ \\
\hline 17 & $8 \rightarrow 7$ & 0.7779 & 0.778 & $\sqrt{ }$ \\
\hline
\end{tabular}

Keterangan :
1. $\sqrt{ }$
: Nilai Perhitungan Manual Dengan Sistem Memiliki Nilai Yang Sama
2. $\rightarrow$
: Menuju Node

Pada tabel 2 merupakan hasil perhitungan preferensi secara menual dan hasil perhitungan oleh sistem pada aplikasi.

\subsubsection{Pengujian Pencarian Rute Algoritma ACS}

Pada pengujian ini dilakukan perbandingan perhitungan pencarian rute secara manual dan perhitungan pencarian rute oleh sistem pada aplikasi. Paramater alogoritma ACS yang digunakan pada perhitungan manual dengan sistem memiliki nilai yang sama. Berikut adalah nilai dari setiap parameter yang digunakan adalah $\mathrm{q}_{0}=0.4, \alpha=0.1, \beta=1, \rho=0.05, \mathrm{~m}=8$ dan $\mathrm{NCmax}=1$

Pada pengujian ini , nilai intensitas pheromone $\left(\tau_{i j}\right)$ didapatkan dari perhitungan $\tau_{i j}=1 /(n * \operatorname{Lnn})$. Dimana Lnn merupakan jarak antar node dan $\mathrm{n}$ adalah jumlah node. Nilai visibilitas $\left(\eta_{\mathrm{ij}}\right)$ antar node didapatkan dari hasil perhitungan oleh metode SAW yaitu nilai preferensi tiap alternative.

Untuk melakukan perbandingan pencarian rute, diperlukan hasil perhitungan manual dan hasil keluaran pada sistem. Setelah semut menyelesaikan proses pencarian, selanjutnya akan didapatkan rute yang dilalui oleh seluruh semut. Berikut adalah hasil perhitungan pada tiap rute. 
ILKOM Jurnal Ilmiah Volume 10 Nomor 1 April 2018

Tabel 3. Hasil Pencarian Rute Semut Pengujian Rute 1

\begin{tabular}{|c|c|c|c|c|c|}
\hline Semut & Rute & C1 $(\mathrm{KM})$ & C2 & C3 & Visibilitas \\
\hline 1 & $1 \rightarrow 4 \rightarrow 7 \rightarrow 8 \rightarrow 5 \rightarrow 6 \rightarrow 3$ & 1.0358 & 0.6 & 2 & 0,9797 \\
\hline 2 & $1 \rightarrow 4 \rightarrow 7 \rightarrow 8 \rightarrow 5 \rightarrow 6 \rightarrow 3$ & 1.0358 & 0.6 & 2 & 0,9797 \\
\hline 3 & $1 \rightarrow 4 \rightarrow 7 \rightarrow 8 \rightarrow 5 \rightarrow 6 \rightarrow 3$ & 1.0358 & 0.6 & 2 & 0,9797 \\
\hline 4 & $1 \rightarrow 4 \rightarrow 7 \rightarrow 8 \rightarrow 5 \rightarrow 2 \rightarrow 3$ & 0.9945 & 1.0 & 1 & 0.7799 \\
\hline 5 & $1 \rightarrow 4 \rightarrow 7 \rightarrow 8 \rightarrow 5 \rightarrow 6 \rightarrow 3$ & 1.0358 & 0.6 & 2 & 0,9797 \\
\hline
\end{tabular}

Keterangan :

C1 : Panjang Rute Yang Dilalui (Kriteria Jarak).

C2 : Jumlah Bobot Kemacetan Yang Dilalui (Kriteria Kemacetan).

C3 : Banyaknya Hydrant Pada Rute Tersebut (Kriteria Hydrant).

$\rightarrow$ : Menuju Node

Pada tabel 3 merupakan hasil Pencarian Rute Semut pada pengujian rute 1. Dapat diketahui bahwa hasil perhitungan manual algoritma ACS rute $1 \rightarrow 4 \rightarrow 7 \rightarrow 8 \rightarrow 5 \rightarrow 6 \rightarrow 3$ dengan panjang rute $1.0358 \mathrm{KM}$ memiliki nilai visibilitas terbaik. Rute dengan nilai visibilitas terbaik adalah rute optimal yang dipilih

Tabel 4. Hasil Pencarian Rute Semut Pengujian Rute 2

\begin{tabular}{|c|c|c|c|c|c|}
\hline Semut & Rute & C1 $(\mathrm{KM})$ & C2 & C3 & Visibilitas \\
\hline 1 & $1 \rightarrow 4 \rightarrow 7 \rightarrow 8 \rightarrow 5$ & 0.6432 & 0.4 & 1 & 0,7558 \\
\hline 2 & $1 \rightarrow 4 \rightarrow 7 \rightarrow 8 \rightarrow 5$ & 0.6432 & 0.4 & 1 & 0,7558 \\
\hline 3 & $1 \rightarrow 4 \rightarrow 7 \rightarrow 8 \rightarrow 5$ & 0.6432 & 0.4 & 1 & 0,7558 \\
\hline 4 & $1 \rightarrow 4 \rightarrow 5$ & 0.3331 & 0.9 & 0 & 0,6332 \\
\hline 5 & $1 \rightarrow 4 \rightarrow 7 \rightarrow 8 \rightarrow 5$ & 0.6432 & 0.4 & 1 & 0,7558 \\
\hline
\end{tabular}

Keterangan :

C1: Panjang Rute Yang Dilalui (Kriteria Jarak).

C2 : Jumlah Bobot Kemacetan Yang Dilalui (Kriteria Kemacetan).

C3 : Banyaknya Hydrant Pada Rute Tersebut (Kriteria Hydrant).

$\rightarrow$ : Menuju Node.

Pada tabel 4. merupakan hasil Pencarian Rute Semut pada pengujian rute 2. Dapat diketahui bahwa hasil perhitungan manual algoritma ACS dengan rute $1 \rightarrow 4 \rightarrow 7 \rightarrow 8 \rightarrow 5$ dengan panjang rute 0.632 KM memiliki nilai visibilitas terbaik. Rute dengan nilai visibilitas terbaik adalah rute optimal yang dipilih.

Tabel 5 Hasil Pencarian Rute Semut Pengujian Rute 3

\begin{tabular}{|c|c|c|c|c|c|}
\hline Semut & Rute & C1 $(\mathrm{KM})$ & C2 & C3 & Visibilitas \\
\hline 1 & $1 \rightarrow 4 \rightarrow 7 \rightarrow 8$ & 0.4848 & 0.3 & 1 & 1 \\
\hline 2 & $1 \rightarrow 4 \rightarrow 7 \rightarrow 8$ & 0.4848 & 0.3 & 1 & 1 \\
\hline 3 & $1 \rightarrow 4 \rightarrow 7 \rightarrow 8$ & 0.4848 & 0.3 & 1 & 1 \\
\hline 4 & $1 \rightarrow 4 \rightarrow 5 \rightarrow 6 \rightarrow 3 \rightarrow 2$ & Null & Null & Null & Null \\
\hline 5 & $1 \rightarrow 4 \rightarrow 7 \rightarrow 8$ & 0.4848 & 0.3 & 1 & 1 \\
\hline
\end{tabular}

Keterangan :

C1 : Panjang Rute Yang Dilalui (Kriteria Jarak).

C2 : Jumlah Bobot Kemacetan Yang Dilalui (Kriteria Kemacetan).

C3 : Banyaknya Hydrant Pada Rute Tersebut (Kriteria Hydrant).

$\rightarrow$ : Menuju Node.

Pada tabel 5 merupakan hasil Pencarian Rute Semut pada pengujian rute 3. Dapat diketahui bahwa hasil perhitungan manual algoritma ACS dengan rute $1 \rightarrow 4 \rightarrow 7 \rightarrow 8$ dengan panjang rute 0.4848 $\mathrm{Km}$ memiliki nilai visibilitas terbaik. Rute pada semut ke 4 tidak menemui titik tujuan, maka nilai visibilitas memiliki nilai null yang berarti kosong. 

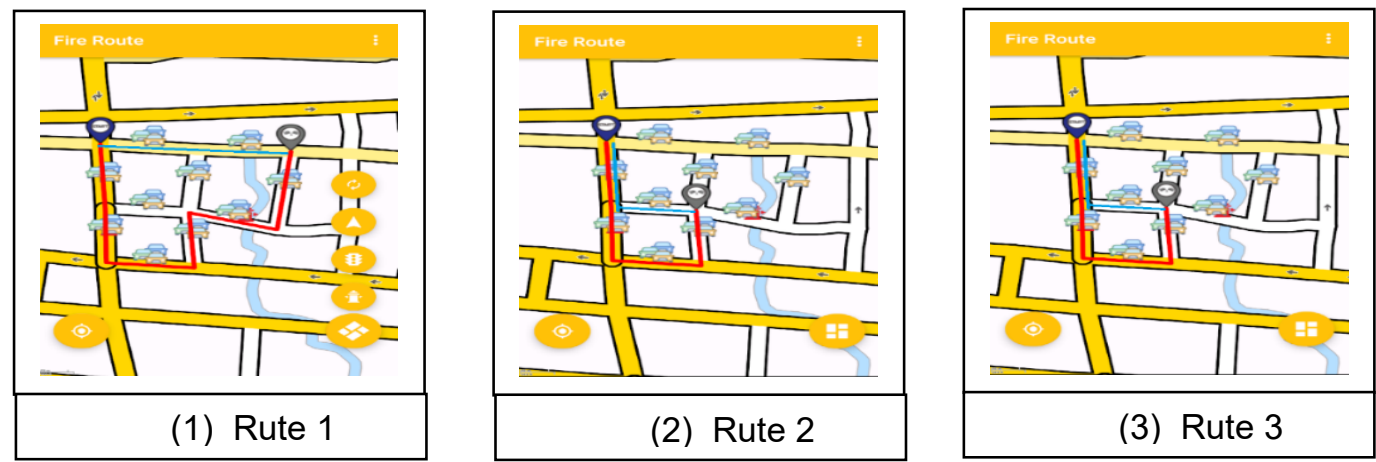

Gambar 8. Hasil Pencarian dengan Rute 1, Rute 2 dan Rute 3 visual peta dari aplikasi

\section{Kesimpulan dan saran}

\subsection{Kesimpulan}

1. Aplikasi pencarian rute terbaik dengan menggunkan algoritma ACO dan metode SAW, dapat digunakan untuk mencari rute optimal berdasarkan kriteria tertentu (jarak, posisi hydrant, dan kemacetan)

2. Algoritma ACO dapat di implementasikan dalam penentuan rute optimal pada perangkat smartphone berbasis Android.

3. Hasil Pencarian Rute Semut pada beberapa pengujian rute, dapat diketahui bahwa hasil perhitungan algoritma ACS untuk rute dan panjang rute yang telah diukur memiliki nilai visibilitas terbaik dan rute dengan nilai visibilitas terbaik adalah rute optimal yang dipilih

\subsection{Saran}

1. Perlu dilakukan pengecekan kembali lajur dan jalur jalan yang ada sehingga didapatkan hasil pencarian rute yang akurat

2. Perlu ditambahan kriteria lain sungai, jalan alternatif dan kepadatan perumahan penduduk guna mendapatkan hasil yang optimal.

\section{Daftar Pustaka}

[1] Yuliyani Siyamtining Tyas dan Widodo Prijodiprodjo. (2013). Aplikasi Pencarian Rute Terbaik dengan Metode Ant Colony Optimazation (ACO). IJCCS, Vol.7, No.1, January 2013, pp. 55 64

[2] Dorigo, M., Maniezzo, V. dan Colorni, A. (1996). Solving Symetric and Asymetric TSPs by Ant Colonies. IEEE Transaction on Systems, Mana and Cybernetics .

[3] Dorigo, M., dan Gambardela, Gambardella, L.M., (1997), Ant Colony System:A CooperativeLearning Approach to the Traveling Salesman Problem, IEEE Transactions on evolutionary computation, vol 1, no 1.

[4] Dorigo, M dan Gambardella, L.M., (1997), Ant Colonies for the travelling Salesman Problem, Bio System 43.

[5] Fishburn, P.C., Additive Utilities With Incomplete Product Set: Applications to Priorities and Assigments, Operations Research.

[6] Janko, W., (2005), Multi-Criteria Decision Making: An Aplication Study of ELECTRE \& TOPSIS.

[7] Zimmermann, 1991, Fuzzy Sets Theory and Its Applications. Edisi 2. Kluwer Academic Publishers. Massachusetts

[8] Kusumadewi, Sri, Sri Hartati, Agus Harjoko dan Retantyo Wardoyo. (2006), Fuzzy Multi-Attribute Decision Making (Fuzzy MADM) ,Graha Ilmu, Yogyakarta.

[9] Ahmed Al-Ani. (2006) "Feature Subset Selection using Ant Colony Optimization". International Journal of Computational Intelligence.

[10] Andrea Roli. (2002) "Ant Colony Optimization". Aironews Vol.7 no.3 (Pages1-3).

[11] Agus Leksono.(2009) "Algoritma Ant Colony Optimization (ACO) Untuk Menyelesaikan Traveling Salesman Problem (TSP)". Fakultas Matematika dan IImu Pengetahuan Alam. Universitas Diponegro 